\title{
UJI AKTIVITAS HEPATOPROTEKTIF TEH HIJAU KOMBUCHA PADA TIKUS PUTIH YANG DIINDUKSI PARASETAMOL
}

\author{
M.Thesa Ghozali ${ }^{1 *}$, Puguh Novi Arsito ${ }^{2}$ \\ ${ }^{1,2}$ Department of Pharmacy, Faculty of Medicine and Health Science, \\ Universitas Muhammadiyah Yogyakarta \\ *e-mail: mt_ghozali@ymail.com
}

\begin{abstract}
ABSTRAK
Parasetamol adalah obat analgesikantipiretik yang mempunyai efek hepatotoksik ketika digunakan pada dosis yang tinggi. Toksisitas parasetamol ini disebabkan karena pembentukan senyawa racun dari beberapa bagian obat yang dimetabolisme oleh sitokrom P450. Penelitian ini bertujuan untuk menguji aktivitas hepatoprotektif teh hijau kombucha pada tikus albino galur wistar. Gangguan hati akut dilakukan dengan cara menginduksi parasetamol dengan dosis $740 \mathrm{mg} / \mathrm{kg}$ BB. Teh hijau kombucha diberikan dengan 0,5, 1,0, dan $1,5 \mathrm{ml}$ peroral diberikan selama 7 hari. Parameter biokimia hati (kadar SGOT, SGPT) diukur dengan menggunakan spektrofotometer, dan kemudian dicatat berat hati tikus (bobot per 100 gram). Hasil penelitian menunjukkan bahwa teh hijau kombucha dengan dosis yang sudah ditentukan dapat mencegah peningkatan bobot hati tikus secara signifikan dengan nilai $p<0,05$ ketika dibandingkan dengan kelompok hewan uji yang diinduksi parasetamol. Teh hijau kombucha dengan dosis $1,0 \mathrm{ml}$ lebih efektif dari dosis laim 0,5 dan 1,5 ml. Teh hijau kombucha memberikan efek hepatoprotektif secara signifikan dengan nilai $\mathrm{p}<0,05$ dengan menurunkan aktitivas enzim serum seperti SGOT dan SGPT. Teh hijau kombucha dengan dosis $1,0 \mathrm{ml}$ juga efektif menurunkan kadar SGOT dan SGPT. Kesimpulan dari penelitian ini adalah teh hijau kombucha mempunyai aktivitas hepatoprotektif yang baik.
\end{abstract}

Kata kunci: efek hepatoprotektor, parasetamol, teh hijau kombucha

\section{ABSTRACT}

Paracetamol is an analgesicantipyretic drug that has hepatotoxic effect when taken in high doses. Paracetamol toxicity is due to the formation of toxic metabolites when a part of it is metabolized by cytochrome P450. This study was designed to evaluate the hepatoprotective activity of green kombucha tea (GKT) in wistar albino rats. Acute liver injury was induced by paracetamol $(750 \mathrm{mg} / \mathrm{kg}$, b.w). GKT at the dose of $0.5,1.0$, and $1.5 \mathrm{ml}$, p.o was administered for 7 days. The biochemical parameters of liver such as serum glutamate oxaloacetate transaminase (SGOT), glutamate pyruvate transaminase (SGPT) levels were measured using spectrophotometer. Finally, the liver weight $(\mathrm{Wt} / 100 \mathrm{~g} \mathrm{b.w})$ of rats were recorded. GKT in all doses prevented the increase of liver weight significantly $(p<0.05)$ when compared with paracetamol treated rats. The dose 1.0 $\mathrm{ml}$ of GKT was found to be the most effective than the other dose $(0.5$ and $1.5 \mathrm{ml})$. GKT produced hepatoprotective effect significantly $(p<0.05)$ by decreasing the activity of serum enzyme such us SGOT and SGPT. The 1.0 $\mathrm{ml}$ dose of GKT also found to be the most effective dose to decrease the levels of SGOT and SGPT. It is concluded that the Green kombucha tea possesses good hepatoprotective activity.

Keywords: green kombucha tea, hepatoprotective effect, paracetamol

\section{PENDAHULUAN}

Kecenderungan meningkatnya prevalensi penderita hepatitis memerlukan penanganan yang baik, karena sebagian 
besar hepatitis dapat menjadi kronis yang akan berlanjut menjadi sirosis dan kanker hati, serta berakhir dengan kematian akibat kegagalan fungsi hati (Anonim, 2004).

Salah satu obat tradisional yang diduga memiliki sifat sebagai hepatoprotektor adalah kombucha tea atau lebih dikenal dengan nama jamur teh atau jamur dipo (Anonim, 2006). Kombucha tea sudah banyak dilaporkan khasiatnya dalam hal medis seperti sebagai anti diabetes, anti hipertensi, dan anti inflamasi (Frank, 1995).

Kombucha tea merupakan cairan teh hasil fermentasi dibawah kondisi aerobik bakteri acetobacter xylinum dan ragi saccharomyces sereviceae dalam masa zoogela serupa nata yang disebut "nata de tea" atau biasa dikenal sebagai kombucha colony (Frank, 1995). Kultur kombucha tumbuh di dalam medium teh manis yang kemudian akan menghasilkan berbagai macam metabolit yang sangat berguna bagi kesehatan, seperti asam malat, asam oksalat, beberapa macam asam amino, dan terutama asam glukoronat (Frank, 1995).

Asam glukoronat sendiri merupakan senyawa endogen yang bekerja pada metabolisme fase dua yang berkonjugasi dengan senyawa-senyawa toksik (Katzung, 1998). Berdasarkan kandungan asam glukoronat tersebut, maka penelitian ini kemudian dilakukan untuk mengetahui efek hepatoprotektif Kombucha tea secara in vivo terinduksi Parasetamol dengan parameter kadar SGOT \& SGPT.

\section{METODE PENELITIAN}

Subyek uji yang digunakan adalah tikus putih (Rattus norvegicus L.) jantan umur 40-60 hari, dengan berat badan sekitar
20-30 g (diperoleh dari Laboratorium Farmakologi dan Toksikologi Prodi Farmasi Fakultas Kedokteran \& IImu Kesehatan Universitas Muhammadiyah Yogyakarta). Bahan dan alat yang digunakan pada penelitian ini adalah kombucha tea berstandar, sebagai obyek uji, yang diperoleh dari hasil pembiakan sendiri, parasetamol yang dibeli di Brataco, kit SGOT \& SGPT merek Dyasis (Jerman), dan pakan tikus yang menggunakan BR-2.

Alat-alat yang digunakan adalah peralatan bedah (gunting, pinset), alat-alat gelas yang lazim digunakan (gelas beker, gelas ukur, labu takar, dan gelas arloji), cawan porselen, pipet, mortir dan stamper, jarum suntik oral volume $3 \mathrm{ml}$ (terumo syiringe), ependroff, sentrifus mikrolab 300 (Merk, Germany), tabung reaksi, timbangan elektrik, dan timbangan tikus.

Dosis Parasetamol dan kombucha tea ditetapkan berdasarkan hasil orientasi (percobaan pendahuluan) $750 \mathrm{mg} / \mathrm{kgBB}$. Pengambilan darah dilakukan dari sinus orbitalis mata. Serum tikus digunakan dalam mengukur aktivitas SGOT \& SGPT secara spektrofotometri menggunakan metode kinetik GPT-alat. Analisis histopatologi dilakukan menggunakan hati tikus yang disimpan dalam larutan formalin 10\% untuk pembuatan preparat histopatologi sel hati.

Tikus secara acak dibagi menjadi 5 kelompok. Kelompok I untuk kontrol positif diberikan parasetamol dengan dosis 750 $\mathrm{mg} / \mathrm{kg}$ BB. Kelompok II untuk kontrol negatif tidak diberi perlakuan apapun. Kelompok III $\checkmark$ untuk uji aktivitas hepatoprotektif diberi parasetamol dengan dosis $750 \mathrm{mg} / \mathrm{kg}$ BB yang sebelumnya sudah diberi teh kombucha dengan variasi dosis sebesar 1,5 $\mathrm{ml}, 1 \mathrm{ml}$, dan $0,5 \mathrm{ml}$ secara oral dua kali 
sehari selama enam hari berturut-turut dan kemudian diberi. Serum dibuat dengan cara menampung darah tikus dalam ependroff yang telah diberi heparin secukupnya.
Kemudian di centrifuge dengan kecepatan 3500 rpm selama 10 menit. Supernatan yang terbentuk merupakan serum darah.

\section{HASIL DAN PEMBAHASAN}

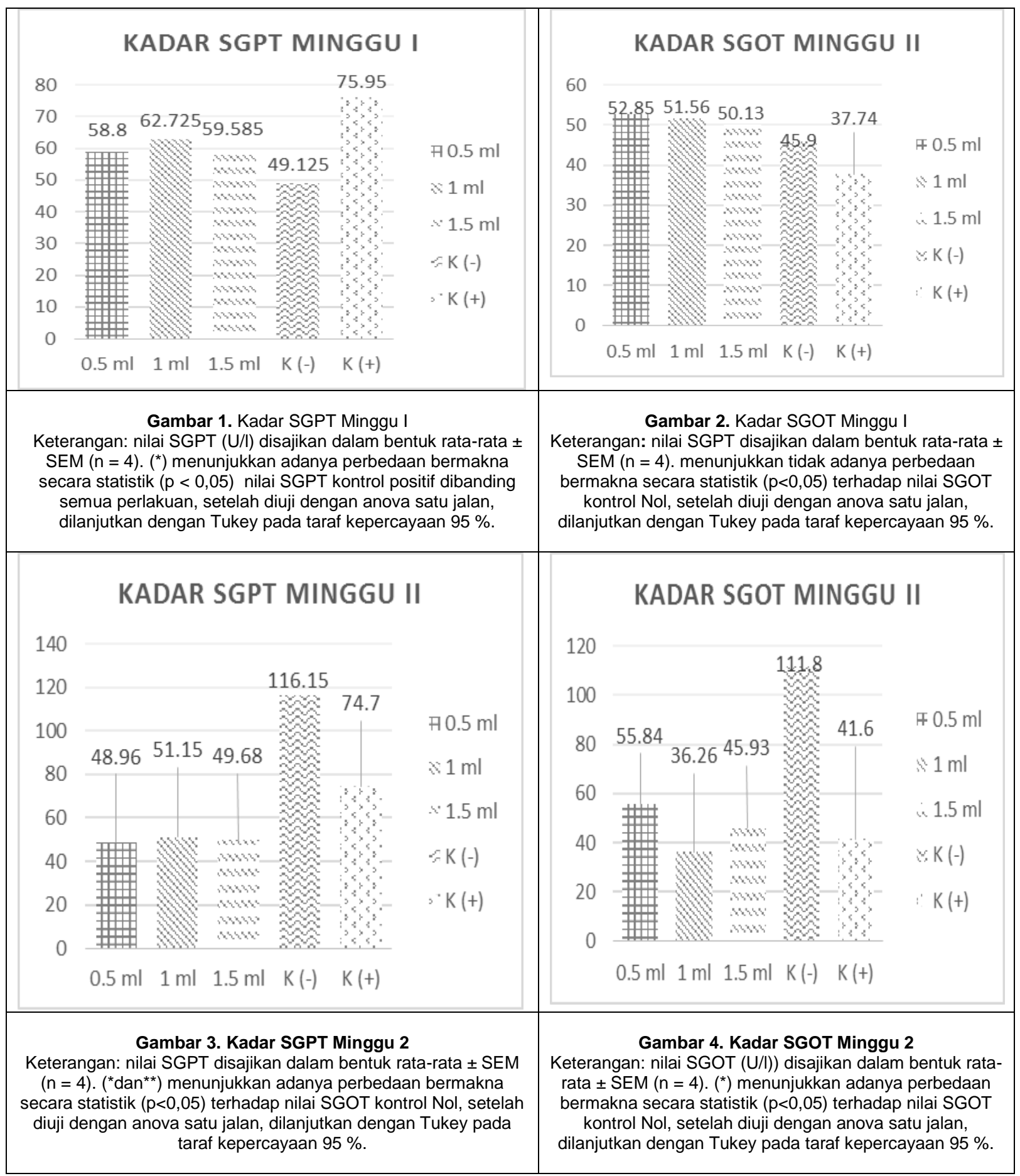




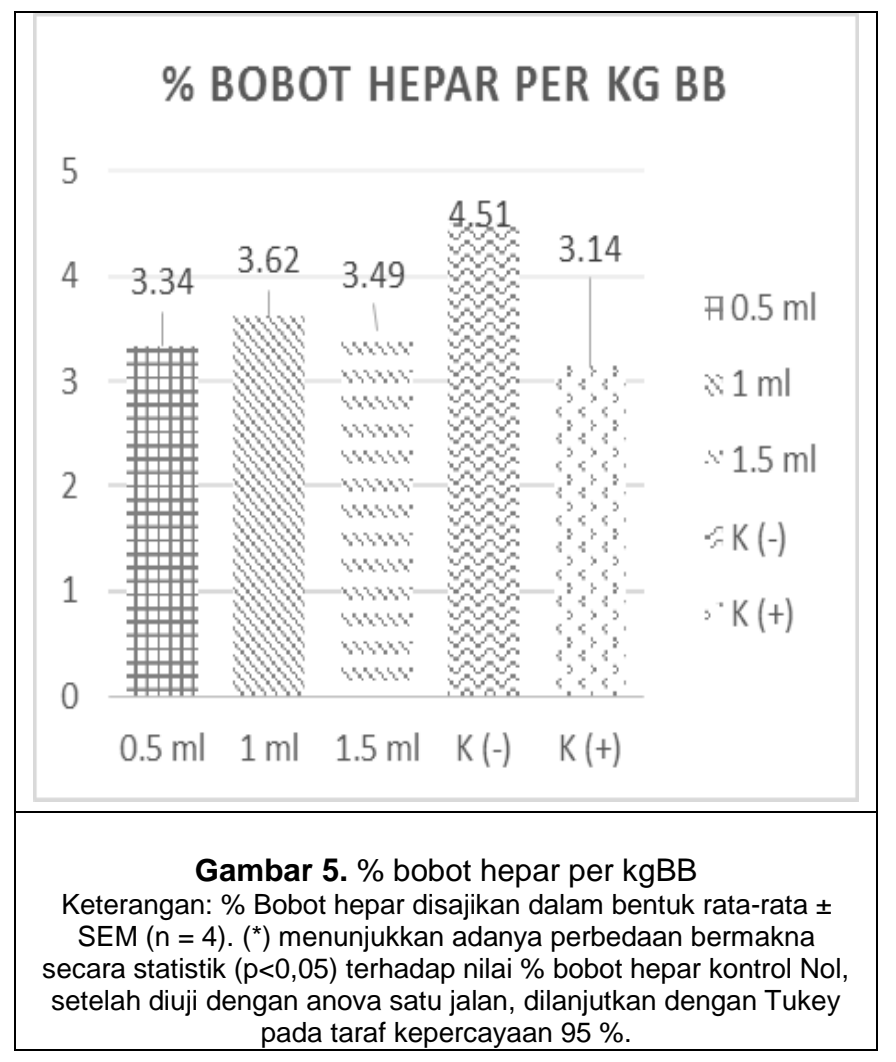

Penelitian ini menggunakan teh hijau sebagai sumber kombucha. Teh hijau seberat $20 \mathrm{~g}$ diseduh terlebih dahulu dengan menggunakan air mineral 1 liter. Penggunaan teh hijau memiliki beberapa keuntungan apabila dibandingkan dengan teh hitam. Teh hijau memiliki kapasitas antioksidan yang lebih tinggi dibanding teh hitam. Hal ini dikarenakan kandungan Epigalo catechin gallat (EGCG) yang lebih tinggi pada teh hijau. Apabila menggunakan teh hitam maka kandungan EGCG akan rendah (Frank, 1995). Penggunaan air mineral dikarenakan dalam pertumbuhan jamur kombucha juga diperlukan mineral. Apabila digunakan aquadest maka suplai mineral tidak dapat terpenuhi (Frank, 1995). Sumber karbohidrat yang digunakan pada kultur berasal dari sukrosa sebanyak $20 \mathrm{~g}$. Sukrosa ini merupakan precursor dari pembentukan asam glukoronat yang diduga berkhasiat sebagai hepatoprotektor. Dari hasil optimasi diketahui waktu kultur optimal adalah 7 hari. Pada hari ke-7 ini diketahui rata-rata $\mathrm{pH}$ larutan kombucha adalah 3 . Larutan kombucha dipersiapkan berbeda kultur tiap harinya, sehingga kualitas larutan yang diberikan ke hewan uji bersifat seragam tiap harinya. Apabila digunakan kultur yang sama pada kurun waktu tertentu, maka $\mathrm{pH}$ larutan turun terlalu rendah, sehingga kualitasnya tidak sama.

Hewan uji yang digunakan pada penelitian ini adalah tikus putih galur wistar dengan berat badan rata-rata $200 \mathrm{~g}$. Pemeriksaan sederhana dan rutin yang dilakukan untuk pemeriksaan fungsi hepar adalah pemeriksaan SGPT dan SGOT. Enzim SGPT terikat dalam sitoplasma sel hepar sedangkan enzim SGOT terikat dalam 
organel sel hepar. Apabila sel hepar mengalami nekrosis maka akan terjadi kenaikan kadar kedua enzim ini dalam serum. Walaupun SGPT dan SGOT sering dianggap sebagai enzim hepar karena tingginya konsentrasi keduanya dalam hepatosit, namun hanya SGPT yang spesifik terhadap hepar jika dibandingkan dengan SGOT mengingat SGOT juga terdapat pada otot jantung, otot tubuh, ginjal dan pankreas (Joyce, 2007). Sebelum dilakukan percobaan, tikus dikondisikan terlebih dahulu selama 1 minggu. Selama 1 minggu ini tikus hanya diberikan pakan saja. Setelah kondisi tikus stabil, maka dilanjutkan dengan pemberian larutan kombucha selama 1 minggu. Setelah 1 minggu pemberian larutan kombucha, dilakukan pengambilan sampel darah periode pertama. Pada periode pertama ini belum dilakukan pemberian hepatotoksin. Setelah pengukuran SGPT/SGOT periode 1 dilakukan, maka langkah selanjutnya adalah pemberian hepatotoksin bersama dengan larutan kombucha selama 1 minggu. Setelah 1 minggu kadar SGPT/SGOT kembali diukur. Berikut adalah data kadar SGOT dan SGPT tikus pada periode pertama dan kedua.

Pada periode atau minggu 1 (sebelum pemberian hepatotoksin) diketahui kadar SGPT antar kelompok adalah sama. Perbedaan hanya terjadi pada kadar SGPT kelompok kontrol negatif. Meskipun perbedaan tersebut bermakna secara statistik $(p<0,05)$, namun diketahui kadar SGPT tersebut masih normal (75,95 U/l). Kadar SGPT dikatakan tinggi apabila telah mencapai $2 \times 40 \mathrm{U} / \mathrm{l}$. Variasi tersebut terjadi kemungkinan karena fluktuasi kondisi fisiologis hewan uji saja sehingga secara keseluruhan disimpulkan bahwa pada periode pertama kadar SGPT hewan uji normal. Pada periode 2 (setelah pemberian hepatotoksin) diketahui sudah diketahui perbedaan kadar SGPT. Untuk kadar SGPT kontrol negatif terlihat mencapai kadar 116,15 U/l. Apabila kadar SGPT mencapai kadar ini diketahui bahwa sudah terjadi kondisi hepatotoksik. Sedangkan pada kelompok perlakuan lain, diketahui kadar SGPT nya masih normal. Kadar SGPT tersebut diketahui berbeda signifikan dengan kontrol negatif $(p<0,05)$. Kadar SGPT terendah dicapai oleh kelompok dosis $0,5 \mathrm{ml}$, yaitu 48,96 U/l. Selain itu dari hasil interpretasi data kadar SGPT antar kelompok perlakuan kombucha $(0,5 \mathrm{ml}, 1 \mathrm{ml}$, $1,5 \mathrm{ml}$ ) diketahui dengan semakin meningkatnya pemberian dosis kombucha tidak berkorelasi dengan semakin turunnya kadar SGPT sehingga diketahui penurunan kadar SGPT tersebut tidak bergantung pada dosis (non dose dependent). Pada dosis $\mathrm{k}$ (0) diketahui juga terjadi penurunan kadar SGPT.

Pada periode 1 (sebelum pemberian hepatotoksin) diketahui kadar SGOT antar kelompok tidak berbeda secara statistik $(p<0,05)$ sehingga secara keseluruhan disimpulkan bahwa pada periode pertama kadar SGOT hewan uji normal. Pada periode 2 (setelah pemberian hepatotoksin) diketahui sudah diketahui perbedaan kadar baik SGOT. Untuk kadar SGOT kontrol negatif terlihat mencapai kadar 111,80 U/I. Apabila kadar SGOT mencapai kadar ini diketahui bahwa sudah terjadi kondisi hepatotoksik. Sedangkan pada kelompok perlakuan lain, diketahui kadar SGOT nya masih normal. Kadar SGOT tersebut diketahui berbeda signifikan dengan kontrol negatif $(p<0,05)$. Kadar 
SGOT terendah dicapai oleh kelompok dosis $1 \mathrm{ml}$, yaitu 36,26 U/I. Selain itu, dari hasil interpretasi data kadar SGOT antar kelompok perlakuan kombucha $(0,5 \mathrm{ml}, 1 \mathrm{ml}$, $1,5 \mathrm{ml}$ ) diketahui dengan semakin meningkatnya pemberian dosis kombucha tidak berkorelasi dengan semakin turunnya kadar SGOT sehingga diketahui penurunan kadar SGOT tersebut tidak bergantung pada dosis (non dose dependent).

Pada percobaan ini diketahui bahwa teh hijau kombucha mampu menurunkan kadar SGOT/SGPT pada tikus yang teinduksi paracetamol dosis hepatotoksik. Salah satu toksisitas parasetamol adalah karena obat ini dimetabolisme oleh enzim CYP450 menjadi produk antara yang sangat reaktif yaitu NAPQI (N-Acetyl-P-Benzoquinone Imine) (Katzung, 1998). Secara alamiah tubuh mampu membuang senyawa ini dengan jalan mengkonjugasikannya membentuk metabolit merkapturat dengan bantuan enzim GSH (Glutathion). NAPQI sebenarnya hanya diproduksi dalam jumlah kecil, namun tipe ikatannya dengan sel hepatosit bersifat kovalen. Ikatan kovalen diketahui bersifat kuat sehingga dapat memicu kerusakan sel hepatosit. Apabila kondisi hepatotoksik berlangsung lama, maka akan mengarah ke nekrosis (kematian) sel hepatosit.

Salah satu manifestasi kerusakan hepar adalah terjadinya kondisi pembengkakan dan perlemakan hepar (Frances, 1992). Kondisi ini dapat diamati dengan mengukur perbedaan bobot hepar pasca uji periode 2 sehingga pada penelitian ini juga dibandingkan bobot hepar pasca uji periode 2. Dari data tersebut diketahui bahwa terjadi peningkatan bobot hepar yang tinggi pada kelompok kontrol negatif $(4,51 \%$
kgBB). Hal ini mengindikasikan telah terjadinya tanda-tanda hepatotoksisitas pada hepar. Perbedaan tersebut berbeda secara statistik dengan semua kelompok perlakuan $(p<0,05)$. Pada saat pembedahan juga terlihat adanya steatosis pada hepar. Steatosis merupakan penimbunan atau akumulasi lemak dalam sel-sel yang biasanya memetabolisme lemak. Hal ini diakibatkan karena kerja hati yang berat akibat gangguan hepatotoksin. Transfer lipid keluar dari hepar menjadi terhambat dan terakumulasi dalam hati. Degenerasi ini bisa terjadi secara mikrovasikuler maupun makrovasikuler. Sel-sel yang mengalami degenerasi ini perubahannya bersifat reversibel. Apabila dibiarkan lebih lanjut kondisi ini bisa berkembang kearah sirosis atau nekrosis. Apabila dilakukan perbandingan \% bobot hepar kelompok perlakuan kombucha $(0,5,1$, dan $1,5 \mathrm{ml})$ dengan $k(0)$ diketahui tidak terjadi perbedaan yang signifikan secara statistik $(p<0,05) \quad$ sehingga diketahui kondisi hepatotoksik tidak terjadi pada kelompok ini. Selain itu dari hasil interpretasi data \% bobot hepar antar kelompok perlakuan kombucha $(0,5 \mathrm{ml}, 1 \mathrm{ml}, 1,5 \mathrm{ml})$ diketahui dengan semakin meningkatnya pemberian dosis kombucha tidak berkorelasi dengan semakin turunnya \% bobot hepar. Sehingga diketahui penurunan \% bobot hepar tersebut tidak bergantung pada dosis (non dose dependent).

Hasil penelitian ini secara keseluruhan diketahui bahwa teh hijau kombucha memiliki efek hepatoprotektif pada tikus yang terinduksi parasetamol dosis hepatotoksik. Mekanisme hepatoprotektor secara umum dapat terjadi melalui beberapa cara yaitu: 
1. Meningkatkan produksi dan aktivitas enzim GSH. Dengan mekanisme ini akan mempercepat terjadinya pembuangan metabolitmetabolit toksik parasetamol dengan bentuk merkapturat. Mekanisme ini belum terungkap melalui penelitian ini.

2. Meningkatkan produksi dan aktivitas enzim glukoronil transferase. Dengan mekanisme ini juga akan mempercepat terjadinya pembuangan metabolit-metabolit toksik parasetamol dengan bentuk glukoronat. Mekanisme ini belum terungkap melalui penelitian ini.

3. Meningkatkan ketersersediaan substrat glukoronat. Mekanisme ini diduga merupakan mekanisme kerja yang dimiliki oleh teh kombucha. Seperti yang sudah diketahui sebelumnya kombucha memiliki kandungan glukoronat yang potensial

4. Berperan sebagai antioksidan. Metabolit reaktif (radikal bebas) yang dapat memicu terjadinya hepatotoksik akan ditangkap oleh antioksidan (radical scavengers) sehingga tidak terjadi hepatotoksik. Kandungan antioksidan dari teh kombucha yang tinggi diduga berkontribusi pada tahap ini.

\section{KESIMPULAN}

Pemberian teh hijau kombucha dapat menurunkan kadar SGOT/SGPT tikus yang terinduksi parasetamol dosis hepatotoksik. Penurunan kadar SGOT/SGPT tikus yang terinduksi parasetamol bersifat tidak tergantung pada seberapa besar dosis teh hijau kombucha yang diberikan (non dose dependent).

\section{DAFTAR PUSTAKA}

Anonim, 2004, Litbang Kesehatan. Tersedia (online).

Anonim, 2006, Kombucha Tea. Tersedia (online)

Frank, G. W., 1995, Kombucha - Healthy Beverage and Natural Remedy From Teh Far East. $9^{\text {th }}$ edition. W. Ennstahler, A-4402 steyr, Austria

Joyce LeFever Kee. 2007. Pedoman Pemeriksaan Laboratorium \& Diagnostik, EGC, Jakarta

Katzung, B. G. .1998. Farmakologi Dasar dan Klinik. Edisi IV. Alih Bahasa : Staf dosen Farmakologi Fakultas Kedokteran UNSRI. Penerbit Buku Kedokteran : Jakarta 